\title{
Pengaruh Parameter Track Quality Indeks (Tqi) Terhadap Perilaku Bantalan Beton
}

(Studi kasus: Track Quality Indeks (TQI) penyimpangan geometri $25 \mathrm{~mm}-40 \mathrm{~mm}$ )

\author{
Wawarisa Alnu Fistcar, ${ }^{1, *}$, Hera Widyastuti ${ }^{1}$, Data Iranata ${ }^{1}$, Catur Arif Prastyanto ${ }^{1}$ \\ Departemen Teknik Sipil, Institut Teknologi Sepuluh Nopember, Surabaya ${ }^{1}$ \\ Koresponden*, Email: wawarisaf@gmail.com
}

\begin{tabular}{lr}
\hline & Info Artikel \\
\hline Diajukan & 12 Desember 2019 \\
Diperbaiki & 23 Januari 2020 \\
Disetujui & 24 Januari 2020
\end{tabular}

Keywords: Track quality indexs (TQI), concrete sleeper, axial load, lateral load, stress

Kata kunci: Track kualitas indeks (TQI), bantalan beton, beban aksial, beban lateral tegangan.

\begin{abstract}
Quality calculation of the railway geometry can be obtained using the standard Indonesian railway formula. The results of calculations for KA Galunggung in 2018 obtained a maximum value of 37.44. While for KA.EM-120 in 2019, the maximum value of 40.75 will be obtained. The results of the calculation of the two geometric qualities have different values, which are then used as benchmarks for measurements made manually. Actual geometry values with geometry deviations $25 \mathrm{~mm}-40 \mathrm{~mm}$, then modeled with software assistance programs with Finite Element Method (FEM) simulation. The dimensions and material properties are in accordance with the conditions at the study site, the dimensions of concrete sleeper type $\mathrm{N}-67$ $=2000 \times 250 \times 215 \mathrm{~mm}$, material properties $\left(F^{\prime}{ }^{\prime}\right)=54 \mathrm{MPa}$ with tensile strength prestressed wire $=1400 \mathrm{MPa}$, rail type 54 and ballast material used in accordance with PM.60 of 2012. Axial load that works according to the calculation of passing tonnage 16,241 $\mathrm{kg}$, with lateral loads according to the conditions of deviation and load distribution on each sleeper. From the results of the analysis on the value of deviation of category $3(25<T Q I<40)$, concrete sleeper experiences a maximum compressive stress of 24,229 MPa and a maximum tensile stress of $5,436 \mathrm{MPa}$. The results of the analysis of concrete sleeper can not withstand the required tensile force of a maximum of 4,632 MPa (0.32 Fc0.67). So the maximum geometry deviation requirements must not exceed category 2 (TQI $\max <25 \mathrm{~mm})$, if the geometry deviation values are in category 2 then treatment investigations should be carried out.
\end{abstract}

\begin{abstract}
Abstrak
Perhitungan kualitas geometri jalan rel dapat diperoleh dengan menggunakan rumus standar perkeretaapian Indonesia. Hasil perhitungan untuk KA. Galunggung tahun 2018 memperoleh nilai maksimum sebesar 37,44. Sedangkan untuk KA.EM-120 pada tahun 2019 memperoleh nilai maksimum sebesar 40,75. Hasil perhitungan kedua kualitas geometri tersebut memiliki perbedaan nilai, yang selanjutnya dijadikan tolak ukur untuk pengukuran yang dilakukan secara manual. Nilai geometri aktual dengan penyimpangan geometri $25 \mathrm{~mm}-40 \mathrm{~mm}$, selanjutnya di modelkan dengan progam bantu perangkat lunak dengan simulasi Finite Elemen Method (FEM). Dimensi serta propeti material sesuai dengan keadaan yang ada di lokasi penelitian, dimensi bantalan beton tipe $N-67=2000 \times 250 \times 215$ $\mathrm{mm}$, properti material $\left(\mathrm{F}_{\mathrm{c}}{ }^{\prime}\right)=54 \mathrm{MPa}$ dengan kuat tarik wire prestressed $=1400 \mathrm{MPa}$, tipe rel 54 dan material balas yang digunakan sesuai dengan PM.60 tahun 2012. Beban aksial yang bekerja sesuai perhitungan passing tonnage $16.241 \mathrm{Kg}$, dengan beban lateral sesuai kondisi penyimpangan serta distribusi beban pada setiap bantalan. Dari hasil analisa pada nilai penyimpangan kategori $3(25<\mathrm{TQI}<40)$, bantalan mengalami tegangan tekan maksimum 24.229 MPa dan tegangan tarik maksimum sebesar 5.436 MPa. Hasil analisa tersebut bantalan tidak dapat menahan gaya tarik yang dipersyaratkan yaitu maksimal 4.632 MPa $\left(0.32 \mathrm{Fc}^{0.67}\right)$. Jadi disarankan penyimpangan geometri tidak boleh melebihi kategori 2 (TQI max $<25 \mathrm{~mm}$ ), jika nilai penyimpangan geometri sudah masuk pada kategori 2 maka harus dilakukan investigasi perawatan.
\end{abstract}

\section{Pendahuluan}

Pulau Jawa merupakan salah satu Pulau dengan jaringan konektivitas perkeretapian terbesar di Indonesia dalam fungsi operasionalnya salah satunya yaitu jalur kereta api Surabaya - Mojokerto, jalur kereta api Surabaya - Mojokerto merupakan jalur utama di jalur rel kereta api lintas selatan Pulau Jawa . Jalur ini merupakan jalur kereta api dengan jadwal perjalanan tersibuk di Indonesia[1]. Hal tersebut dikarenakan jalur ini adalah jalur selatan yang menghubungkan Surabaya - Jogjakarta. Jalur ini sedang ada penambahan jalur ganda (doble track) yang dikerjakan bertahap. Jalur Surabaya Mojokerto adalah jalur yang belum dilakukan penambahan track yaitu tepatnya pada resor 8.13 dan 8.14 (Survey). Jalur ini termasuk dalam wilayah Daerah Operasi VIII Surabaya. Surabaya adalah pusat ekonomi Jawa Timur dimana 
efektifitas insfrastruktur transportasi sangat penting untuk menjaga pertumbuhan ekonomi[2].

Lalu lintas kereta api akan terus meningkat sesuai dengan perkembangan ekonomi. Karena kereta api adalah moda transportasi darat yang hampir bisa dipastikan ketepatan waktunya. Hal tersebut dapat mempengaruhi kondisi geometri lintasan yang menyebabkan terjadinya penurunan kualitas lintasan sehingga perlu suatu pemeliharaan untuk mengukur suatu kondisi dan kualitas lintasan. Terkait dengan hal ini, kecelakaan lalu lintas kereta api telah lama menjadi masalah sosial - ekonomi yang telah menyebabkan meningkatnya kekhawatiran masyarakat di seluruh dunia[3]. Perlu diadakannya peningkatan keandalan kondisi dan analisa perbaikan jalan rel kereta api dengan metode pemeliharaan yang tepat sehingga kegagalan pada jalan rel dapat berkurang atau bahkan tidak terjadi. Hal tersebut sangat mungkin terjadi bila struktur jalan rel yang lambat laun mengalami penurunan kualitas tidak dilakukan tindakan. Oleh karena itu, dilakukanlah pemeliharaan untuk mengontrol kinerja operasional kereta api. Namun pelaksanaan pemeliharaan sering terkena dengan masalah biaya yang terbatas maupun terlambat dalam pencairannya, sehingga dana yang ada harus digunakan dengan bijak agar pengalokasiannya tepat sasaran[4], dalam Simposium II -UNIID, 2017. Namun, industri kereta api mencoba meningkatkan produktivitas tim pemeliharaan mereka melalui kontrol yang lebih efektif terhadap kerusakan jalur Di berbagai negara cara mengontrol kualitas jalan rel dilakukan dengan beberapa pendekatan dan metodologi untuk mengevaluasi degradasi jalan rel untuk optimasi pemeliharaan jalan rel, telah dikembangkan selama beberapa tahun terakhir, dari model sederhana yang hanya terkonsentrasi pada satu komponen jalan rel individu hingga yang paling komprehensif yang merangkul semua faktor utama dalam penurunan kualitas lintasan.

Dimensi rel yang digunakan di Indonesia sesuai PD 10 tahun 1986. Penamaan tipe rel untuk tujuan klasifikasi rel di Indonesia disesuaikan dengan berat dalam kilogram, $(\mathrm{kg})$ untuk setiap 1meter panjangnya, misalnya, tipe $\mathrm{R} 54$ berarti rel memliki berat sekitar $54 \mathrm{~kg}$ untuk setiap 1 meter panjangnya. Masing-masing profil rel memiliki dimensi momen inersia, jarak terhadap garis netral luas penampang yang berbeda untuk keperluan perencanaan dan pemilihan dimensi yang tepat untuk struktur jalan rel. Karena ada perbedaan lebar spur sedangkan lebar boogie kereta tetap direncanakan pada lebar spur 1067 mm maka titik pembebanan bisa jadi tidak tepat terhadap garis netral luas penampang yang akan mengakibatkan tegangan pada rel sendiri bervariasi. Tegangan yang diijinkan tergantung pada mutu rel yang digunakan. Untuk perencanaanya PT. Kereta Api Indonesia
(Persero) menggunakan dasar kelas jalan yaitu untuk jalan kelas 1 menggunakan R 60 dan R 54 dengan tegangan ijin $1325 \mathrm{~kg} / \mathrm{cm}^{2}$ [5] Penelitian mengenai pengujian bantalan beton kereta api tipe S35/20 untuk rel R-54/R-60 sudah pernah dilakukan. Pengujian bantalan beton dilakukan menggunakan standar uji AREMA (American Railway Engineering and Maintenance of Way Association). Uji ini meliputi, uji momen negatif dan positif dudukan rel A, uji momen negatif dan positif tengah bantalan, uji momen negatif dan positif dudukan rel $\mathrm{B}$, uji beban berulang dudukan rel B, uji ketahanan geser wire, dan uji bebas ultimate. Kondisi jalur yang handal dan memenuhi persyaratan keselamatan transportasi secara teknis layak untuk dioperasikan dan harus dilakukan pengujian di laboratorium penguji. Dari pengujian yang telah dilakukan atas 3 benda uji, 2 benda uji dinyatakan memenuhi spesifikasi sedangkan 1 benda uji tidak memenuhi spesifikasi diakibatkan adanya retak struktural pada pengujian momen positif terhadap beban desain[6], penelitian tersebut hanya menghasilkan layak atau tidak layaknya bantalan beton akibat beban ultimate dari jalan rel tersebut. Selanjutnya dilakukan penelitian lanjutan yang menghasilkan beban maksimum yang ditumpu pada bantalan adalah $569.601 \mathrm{kN}$ dengan lendutan maksimum $0.681 \mathrm{~mm}$ dan dihitung secara teoritis retak awal terjadi pada beban $256.838 \mathrm{Kn}[7]$.

\section{Metode}

Metode dalam penelitian ini dibagi menjadi 2 garis beasar yaitu mencari nilai track kualitas indek (TQI) yaitu dengan cara analisis setiap parameter kerusakan, perhitungan track kualitas indeks dengan standar kereta api Indonesia, pengukuran dilapangan dan finete elemen bantalan beton dengan program bantu ABAQUS.

2.1 Analisis setiap parameter

Kerusakan pada penelitian ini menggunakan acuan Pedoman standar PT. Kereta Api Indonesia. Track Quality Index (TQI) sendiri terdiri dari 4 parameter pengukuran lebar spur, angkatan, listringan dan pertinggian. Selain parameter tersebut, selama pengukuran juga dicatat kecepatan operasional pengukuran. Pengambilan data ukur dilakukan secara kontinyu sepanjang segment $(200 \mathrm{~m})$. Untuk angkatan, listringan dan pertinggian satu segment mewakili panjang 40 meter. Sedangkan untuk lebar spur satu segmen mewakili panjang 20 meter. Nilai pada setiap kategori tersebut ditampilan dengan satuan panjang (millimeter), dari nilai tersebut terdapat pengelompokan kondisi yaitu dibedakan menjadi 4 kategori yaitu kategori TQI $\leq 15,15<$ TQI $<25$, $25<\mathrm{TQI} \leq 40$ dan $>40$ TQI, jika parameter skilu $3 \mathrm{~mm}$ dihitung maka batas kategori $>50[8]$. TQI ini tidak mempunyai satuan, 
karena walaupun merupakan hasil penjumlahan dari satuan yang sama $(\mathrm{mm})$ tetapi vektomya berbeda. Standar nilai TQI yang digunakan PT. Kereta Api Indonesia (Persero).

\subsection{Track quality indeks (TQI)}

Dihitung menggunakan standar deviasi dari nilai masingmasing segmen standar deviasi yaitu:

$$
S=\sqrt{\frac{\Sigma \mathrm{xi}^{2}-\frac{\Sigma \mathrm{x}^{2}}{n}}{n-1} .}
$$

dengan :

$\mathrm{S} \quad=$ nilai standar deviasi

$\mathrm{xi}^{2} \quad=$ jumlah nilai $\mathrm{x}$ dikuadratkan

$\mathrm{n} \quad=$ jumlah data, maka

TQI = Standar deviasi $\mathrm{x}$ TQI Multiplier

Nilai TQI diperoleh dengan cara mencari nilai standar deviasi yang terjadi pada masing-masing segment. Satu segmen mempunyai 11 (sebelas) record yang mewakili parameter pertinggian, angkatan, listringan, dan lebar spur. Satu record mewakili kerusakan sepanjang 40 meter.

\section{Pengukuran Kondisi Eksisting}

Tahap pengukuran pada kondisi eksisting dapat dilakukan setelah mendapatkan hasil dari nilai analisa Track Quality Index (TQI) dengan nilai kategori jelek. Pada lokasi terjelek akan dilakukan pengukuran kondisi geometri dengan bantuan alat ukur manual yang dapat mengukur beda tinggi dan jarak. Dari hasil pengukuran manual akan didapatkan nilai parameter lebar spur eksisting dan pertinggian eksisting. Untuk parameter listringan dan angkatan dengan mengamati benang setiap 5 bantalan / 4 meter form. metode survey dapat dilihat pada Gambar 1.

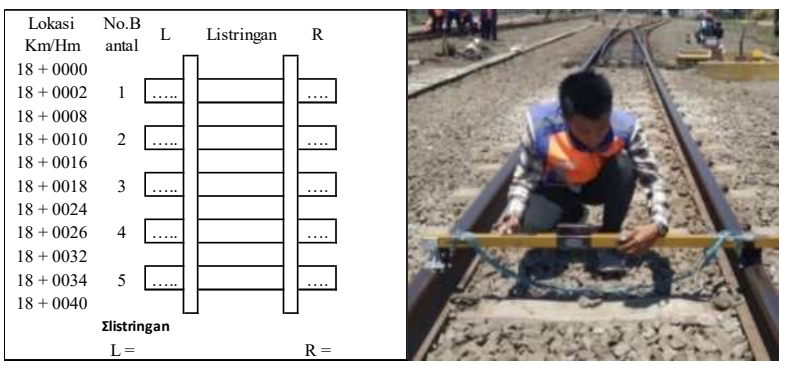

Gambar 1. Form Survey Kondisi Eksisting

\section{Penentuan Kelas Jalan}

Pada penentuan kelas membutuhkan data sekunder yang di dapatkan dari PT. Kereta Api Indonesia Daerah Operasi 8 Surabaya yaitu: grafik perjalanan kereta api/daftar kereta api yang melintas pada ruas Surabaya - Mojokerto, susunan kereta serta berat gerbong yang melintas
Daya angkut lintas jalan rel dapat dinyatakan dengan persamaan:

Beban Lintas $(\mathrm{Pd})=(\mathrm{T} 1)+(\mathrm{Tb})$

Dimana:

$\mathrm{Pd}=$ Beban Lintas Harian Kereta Api (ton)

$\mathrm{Tb}=$ Tonase barang dan gerbong harian (ton)

$\mathrm{Tp}=$ Tonase penumpang dan kereta harian (ton)

Untuk menghitung daya angkut lintas, PT Kereta Api

Indonesia (Persero) menggunakan persamaan:

$\mathrm{T}=360 \times \mathrm{S} \times \mathrm{TE}$

$\mathrm{TE}=\mathrm{Tp}+(\mathrm{Kb} \times \mathrm{Tb})+(\mathrm{K} 1 \times \mathrm{T} 1)$

Dimana:

$\mathrm{T}=$ Kapasitas angkut lintas (ton/tahun),

$\mathrm{T}_{\mathrm{E}} \quad=$ Tonase ekivalen (ton/hari),

$\mathrm{T}_{\mathrm{p}} \quad=$ Tonase penumpang dan kereta harian,

$\mathrm{T}_{\mathrm{b}} \quad=$ Tonase barang dan gerbong harian,

$\mathrm{T}_{1} \quad=$ Tonase Lokomotif harian,

$\mathrm{S} \quad=$ Koefisien yang besarnya bergantung pada kualitas lintas, yaitu:

$\mathrm{S}=1,1$ untuk lintas dengan kereta penumpang dengan kecepatan maksimum $120 \mathrm{~km} / \mathrm{jam}$

$\mathrm{S} \quad=1,0$ untuk lintas tanpa kereta penumpang

$\mathrm{Kb}=$ Koefisien yang besarnya bergantung pada beban gandar, yaitu:

$\mathrm{K}_{\mathrm{b}}=1,5$ untuk beban gandar $<18$ ton

$\mathrm{Kb}=1,3$ untuk beban gandar $>18$ ton

K1 = Koefisien yang besarnya ditentukan sebesar 1,4[9]

Berdasarkan hasil perhitungan pada persamaan 3 maka didapatkan nilai kapisitas angkut lintas dalam satuan (ton/tahun) yang dapat di konversikan pada tabel kelas jalan Peraturan Menteri Perhubungan No. 60 Tahun 2012. Jadi menurut PM.60 Tahun 2012 Kelas Jalan (Tabel 2.6) daya angkut lintas Surabaya - Mojokerto adalah 18.254.753 Ton/tahun masuk dalam Kelas Jalan 2 (10 jt - 20 jt Ton/ Tahun) maka kecepatan maksimum yang diijinkan adalah $110 \mathrm{~km} / \mathrm{jam}$.

\section{Permodelan Nonlinier dengan ABAQUS}

Dari hasil nilai geometri berdasarkan Track Quality Indeks (TQI) maka dapat di modelkan bentuk jalan kereta dengan program bantu ABAQUS dalam satu segmen $3 \mathrm{~m}$ ' sesuai dengan pengecekan dilapangan. permodelan pada KM 18+000 lintas Surabaya - Mojokerto. Input properti material pada ABAQUS didekati dengan persamaan empiris. Persamaan empiris digunakan untuk menentukan hubungan tegangan leleh terhadap regangan plastis pada tekan beton, tarik beton, dan tarik baja tulangan. Perilaku plastis beton ditentukan dengan Concrete Damaged Plasticity (CDP) pada ABAQUS. Input material beton pada ABAQUS terdiri dari elastic behavior dan Concrete Damage Plasticity. Elastic behavior berisi input modulus elastisitas dan poisson ratio [10]. model konstutif tekan beton menggunakan kuat tarik beton 54 Mpa ditunjukan pada Gambar 3 didekati dengan persamaan $\mathrm{F}_{\mathrm{sp}}=0.32\left(\mathrm{~F}_{\mathrm{c}}\right)^{0.67}$ untuk beton no silica fume [11]. sedangkan studi tarik tulangan 1400 Mpa didekati dengan persamaan mander [12].

Jika $\varepsilon_{\mathrm{st}} \leq \varepsilon_{\mathrm{y}}=\sigma_{\mathrm{st}}=\mathrm{E}_{\mathrm{s} .} \varepsilon_{\mathrm{st}}$ 


$$
\begin{aligned}
& \varepsilon_{\mathrm{y}}<\varepsilon_{\mathrm{st}} \leq \varepsilon_{\mathrm{sh}}=\quad \sigma_{\mathrm{st}}=\mathrm{F}_{\mathrm{y}} \\
& \sigma_{\mathrm{st}}=\mathrm{F}_{\mathrm{u}}+\left(\mathrm{F}_{\mathrm{y}}-\mathrm{F}_{\mathrm{u}}\right)\left(\frac{\varepsilon u-\varepsilon s t}{\varepsilon u-\varepsilon s h}\right)^{\mathrm{P}}
\end{aligned}
$$

$\varepsilon_{\mathrm{y}}<\varepsilon_{\mathrm{st}} \leq \varepsilon_{\mathrm{u}}$

$$
\mathrm{P}=\mathrm{E}_{\mathrm{sh}}\left(\frac{\varepsilon u-\varepsilon s h}{F y-F u}\right)
$$

Dimana $f u$ dan $f_{y}$ adalah kuat tarik ultimit dan kuat tarik leleh. $\varepsilon s h$ adalah regangan tarik tulangan saat awal hardening. Ey adalah regangan tegagan tarik tulangan pada saat leleh. $\varepsilon s$ adalah regangan tarik tulangan. $\mathrm{P}$ adalah rasio strain hardening modulus ke secant modulus diantara koordinat awal dan akhir kurva strain hardening [13]. pada perilaku beton didefinisikan ke dalam plastisitas, perilaku tekan, dan tarik. Perilaku tekan didefinisikan ke dalam hubungan inelastic strain-yield stess tekan dan inelastic strain-yield stess tarik [14] seperti yang disajikan pada Gambar 2 dan Gambar 3.

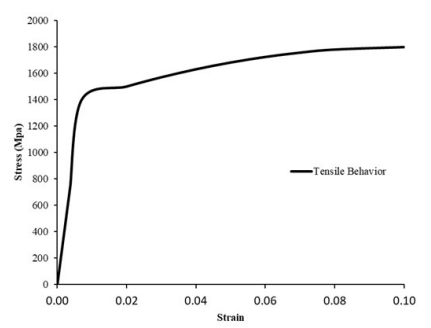

Gambar 2. Kurva Inelastic Strain - Yield stress perilaku tekan $\mathrm{F}_{\mathrm{c}}=54 \mathrm{MPa}$

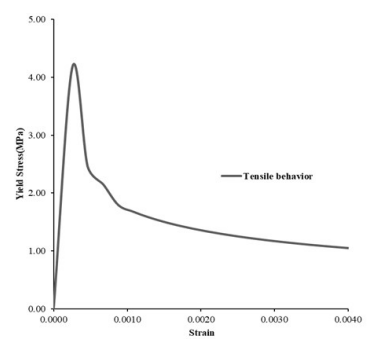

Gambar 3. Kurva Inelastic Strain - Yield stress perilaku tearik $\mathrm{F}_{\mathrm{c}}=54 \mathrm{MPa}$

Kurva perilaku tulangan didekati dengan persamaan mander yang menggambarkan wire prestressed $=1400 \mathrm{Mpa}$ yang dapat dilihat pada Gambar 4

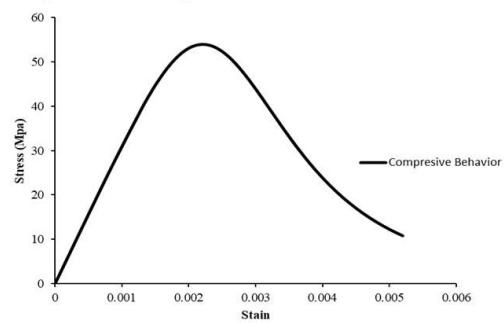

Gambar 4. Kurva strain - stress perilaku tarik tulangan manual Fy $=1400 \mathrm{MPa}$.

\section{Hasil dan Analisa}

6.1 Perhitungan Nilai Track Quality Indeks (TQI)

Hasil perhitungan nilai track quality indeks (TQI) dengan standar perkeretaapian Indonesia menggunakan persamaan 1 yang bersumber dari data sekunder KA. Galunggung dengan data ukur pada tahun 2018. Contoh perhitungan dapat dilihat pada Tabel 1.

Tabel 1. Perhitungan parameter track quality indeks

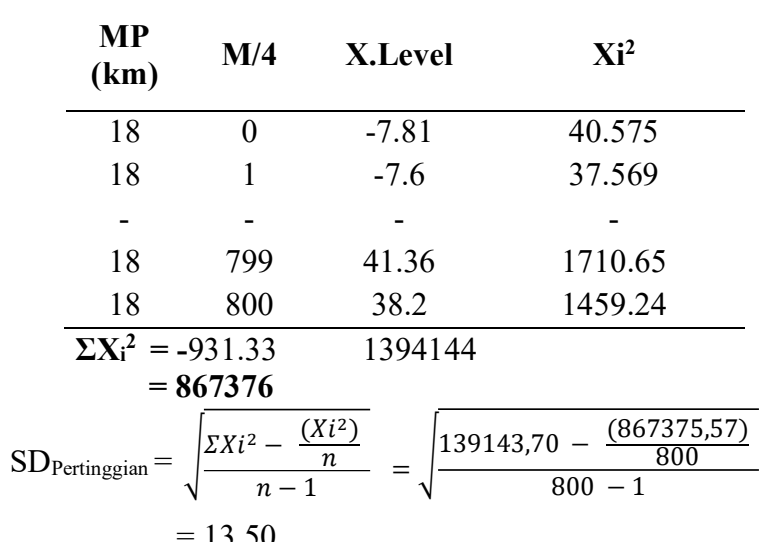

Dari perhitungan seperti diatas nilai track quality indeks pada parameter pertinggian di STA $18+200$ adalah 13.5. dengan cara yang sama didapatkan juga $\mathrm{SD}_{\text {Angkatan }}=$ 11.88509, $\mathrm{SD}_{\text {Listringan }}=6.1234, \mathrm{SD}_{\text {Lebar spur }}=2,63508$. Dari semua hasil tersebut dijumlahkan maka didapatkan nilai TQI pada KM 18-000 - 18+200. Hasil dari nilai track quality indeks adalah per $200 \mathrm{~m}$ ' yaitu sebagai berikut:

$\mathrm{TQI}=\mathrm{SD}$ angkatan $+\mathrm{SD}$ listringan $+\mathrm{SD}$ lebar sepur $+\mathrm{SD}$ pertinggian

$=11,88509+6,12352+2,65085+13,500$

$=33,80864$.

Data sebaran nilai geometri per $25 \mathrm{~cm}$ ' yang di dapatkan adalah dari Direktorat Jendral Perkeretaapian hanya pada tahun 2018, sedangkan data output dari EM-120 milik PT. Kereta Api Indonesia data outputnya langsung keluar nilai yang sudah menjadi nilai track quality indeks per 200 m' pada pengukuran tahun 2019. Hasil kedua data tidak dapat dibandingkan karena sudah lintas tahun yang di gambarkan pada grafik Gambar 5.

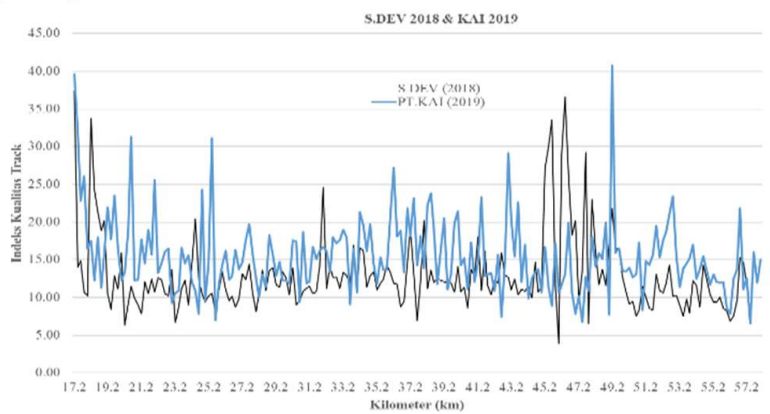

Gambar 5. Nilai track quality indeks tahun 2018 dan 2019 pada lintas Surabaya - Mojokerto 


\subsection{Perhitungan beban eksisting}

Gaya dinamis timbul dari Akibat dari beban dinamik kereta api, maka timbul faktor dinamik. Untuk mentranformasi gaya statis ke gaya dinamis digunakan Persamaan Eisenmann DAF $=1+\mathrm{t} . \varphi(1+(\mathrm{V}-60) / 140)[15]$ dan persamaan Talbot [16]. Dari perhitungan passing tonnage lintas Surabaya - Mojokerto adalah 18.254.753 Ton/tahun masuk dalam Kelas Jalan 2 maka kecepatan masimum ijin adalah $110 \mathrm{~km} / \mathrm{jam}, \mathrm{V}_{\text {rencana }}=1.25 \mathrm{x} \mathrm{V}$.max, maka $137,5 \mathrm{Km} / \mathrm{jam}$.

$$
\begin{aligned}
\mathrm{Pd} & =\operatorname{Ps}\left[1+0.01\left(\frac{\text { V.rencana }}{1.609}-5\right)\right] \\
& =9000\left[1+0.01\left(\frac{137.5}{1.609}-5\right)\right] \\
& =9000[1+0.01(88.225606)] \\
& =9000[1+0.88225606] \\
& =9000[1.88225606] \\
& =16241 \mathrm{Kg} / 16.241 \mathrm{Ton}
\end{aligned}
$$

Distribusi pembebanan seperti pada Tabel 2 dan diilustrasikan pada Gambar 6.
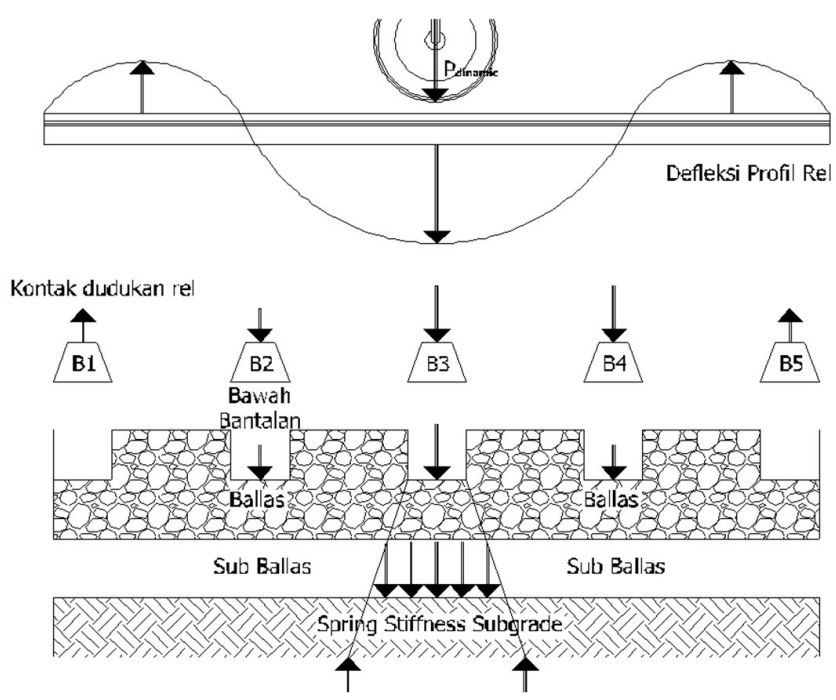

Gambar 6. Ilustrasi letak distribusi pembebanan

Pada pengukuran manual disesuaikan dengan distribusi beban yaitu 3 meteran yang digunakan sebagai dasar letak geometri pada perhitungan Finite Elemen Metode.

Tabel 2. Sebaran pembebanan

\begin{tabular}{lcccccc}
\hline \multirow{2}{*}{ Akibat } & \multicolumn{6}{c}{ Distribusi Beban Aksial } \\
& B1 & B2 & B3 & B4 & B5 & B6 \\
\hline $\mathrm{P}_{\mathrm{d} 1}$ & $23 \%$ & $40 \%$ & $23 \%$ & $7 \%$ & $0 \%$ & $0 \%$ \\
$\mathrm{P}_{\mathrm{d} 2}$ & $0 \%$ & $7 \%$ & $23 \%$ & $40 \%$ & $23 \%$ & $7 \%$ \\
$\mathrm{P}_{\mathrm{d} 3}$ & $0 \%$ & $0 \%$ & $0 \%$ & $7 \%$ & $23 \%$ & $40 \%$ \\
Total & $23 \%$ & $47 \%$ & $46 \%$ & $54 \%$ & $46 \%$ & $47 \%$ \\
\hline Beban & & & & & & \\
(Kg) & $\mathbf{3 8 9 7}$ & $\mathbf{7 9 6 2}$ & $\mathbf{7 7 9 3}$ & $\mathbf{9 1 4 8}$ & $\mathbf{7 7 9 3}$ & $\mathbf{7 9 6 2}$ \\
\hline
\end{tabular}

\subsection{Hasil perilaku bantalan sesuai nilai TQI}

Untuk mengetahui perilaku struktur atas yaitu pada bantalan beton, tulangan, dan rel, analisa struktur harus dilakukan pada setiap modul pengukuran geometri yaitu $3 \mathrm{~m}$ ' (6 Bantalan) dengan beban yang sudah di jelaskan pada Tabel 2 yang dapat dilihat pada Gambar 7.

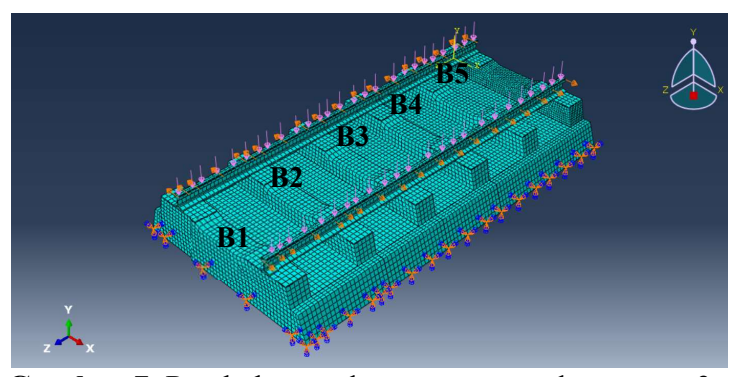

Gambar 7. Pembebanan dan tumpuan pada segmen 3 meter

Tetapi karena keterbatasan perangkat lunak untuk student version ABAQUS maksimum peningkatan (Increment Step adalah 10.000) maka permodelan harus di pecah pada setiap bantalan yang di dapat dilihat pada Gambar 8.

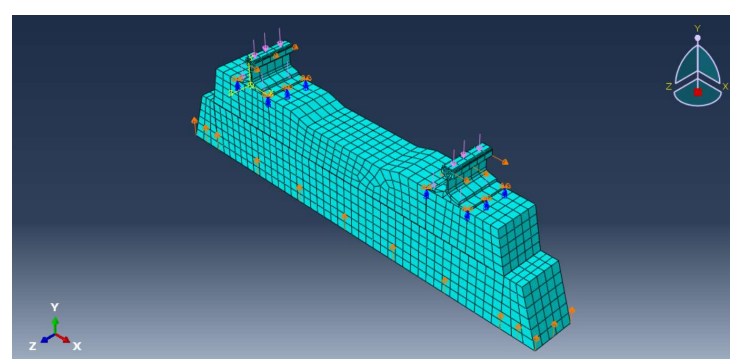

Gambar 8 Pembebanan dan tumpuan pada 1 bantalan

Pada penelitian ini tidak semua jenis tanah di pakai dalam simulasi perhitungan Finite Elemen Method (FEM). Karena pada PM. 60 Tahun 2012 persyaratan tanah dasar harus mempunyai nilai $\mathrm{CBR}>6 \%$, serta mempunyai kepadatan 95 $\%$ maka di pilih 3 jenis tanah yang di jadikan sampel yaitu sebagai berikut:
1. Tanah bagus (Sand dense)
$=128.000 \mathrm{Kn} / \mathrm{m}^{3}$
2. Tanah sedang (silty sand)
$=48.000 \mathrm{Kn} / \mathrm{m}^{3}$
3. Tanah jelek (Clay)
$=24.000 \mathrm{Kn} / \mathrm{m}^{3}[17]$.

Untuk besar momen yang bekerja di ilustrasikan pada Gambar 10 besarnya $P=16.241 \mathrm{Kg}$, dengan ilustrasi kereta jenis CC.201 (Hasil persamaan Talbot) Gambar 9, beban di dapatkan dari passing tonnage pada lintas Surabaya Mojokerto. Dari hasil distribusi beban aksial pada setiap bantalan yang di sajikan pada Tabel 2 di dapatkan beban maksimum adalah pada bantalan kode B4 yaitu 54\% Pdinamis $=0.54 \times 16.241=9.148 \mathrm{Kg}$, sedangkan besarnya $\mathrm{P}_{\text {lateral }}$ dihitung menurut momen maksimum yang bekerja. 


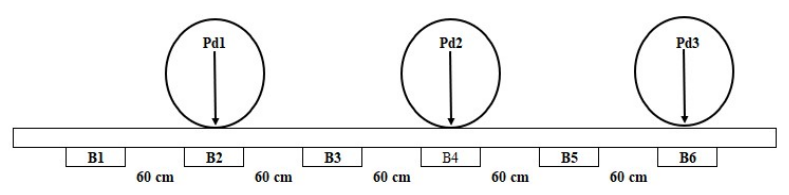

Gambar 9a. Ilustrasi perletakan flange lokomotif C - C

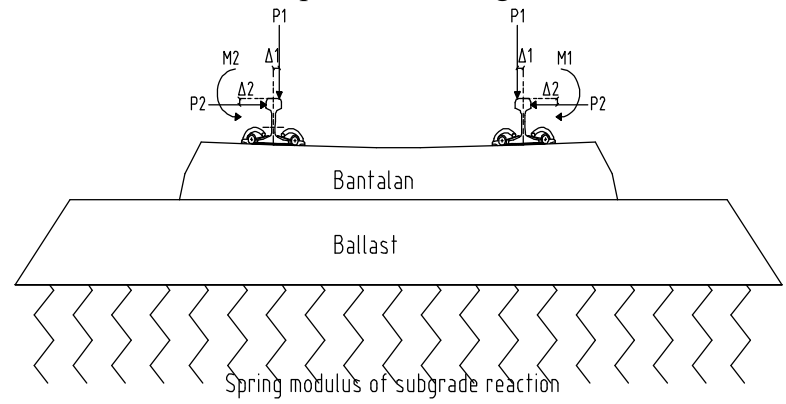

Gambar 9b. Momen yang bekerja akibat penyimpangan TQI

Dari adanya perbedaan penyimpangan sebesar $(\Delta) \mathrm{mm}$ pada arah vertikal maupun horizontal pada setiap kategori penyimpangan TQI maka $\mathrm{P}_{\text {lateral }}$ yang bekerja pada kepala rel berbeda. Nilai $\Delta$ didapatkan dari masing - masing penyimpangan yaitu: arah vertikal = angkatan dan pertinggian, sedangkan arah horizontal $=$ listringan dan lebar spoor. Contoh perhitungan momen pada nilai pentimpangan kategori 3 dengan nilai maximum penyimpangan $25<\mathrm{TQI}<40$ mm sebagai berikut:

$$
\begin{array}{lll}
\sum_{\mathrm{M}} & =0 \\
\mathrm{M}_{1} & =\mathrm{P} 1 . \Delta 1+\mathrm{P} 2 . \Delta 2 \\
\mathrm{M}_{1 \text { TQI } 3} & =9.148 \times 9+9.148 \times 10 \\
& & =173.812 \mathrm{Kg} . \mathrm{mm}
\end{array}
$$

Maka pada kondisi penyimpangan kategori di inputkan $\mathrm{P}_{\text {lateral }}$ sebesar $173.812 \mathrm{Kg}$.mm. Untuk tumpuan model menggunakan variasi Spring modulus of subgrade reaction. Gambar 10 adalah hasil analisa tegangan program dengan kondisi tanah bagus pada kondisi penyimpangan kategori 3, Gambar 11 adalah hasil analisa tegangan program dengan kondisi tanah sedang pada kondisi penyimpangan kategori 3 dan Gambar 12 adalah hasil analisa tegangan program dengan kondisi tanah jelek pada kondisi penyimpangan kategori 3.

Kelemahan program adalah satuan harus menentukan sendiri, input beban adalah dalam satuan berat yaitu $\mathrm{Kg}$ dan input panjang dengan satuan panjang $\mathrm{cm}$. agar satuan sama dengan batas maksimum maka hasil harus di konfersi dalam MPa (megapascal) yaitu sebesar 10.1937 .

Hasil analisa program tegangan tarik (tensile stress) $=$ $0.5331 \times 10.1937=5.436 \mathrm{MPa}$ dan tegangan tekan (compressive stress) $=2.475 \times 10.1937=24.221 \mathrm{MPa}$. Dari hasil analisa maka beton melewati batas tarik beton mutu normal (no silica foam) yaitu sebesar $0.32 \mathrm{~F}_{\mathrm{C}}^{0.67}=0.32 \mathrm{x}$ $54^{0.67}=4.633 \mathrm{MPa}$. Tetapi masih dapat menumpu beban tekan karena hasil analisa tegangan tekan kurang dari $0.85 \mathrm{~F}_{\mathrm{c}}$ $=45.9 \mathrm{MPa}$.

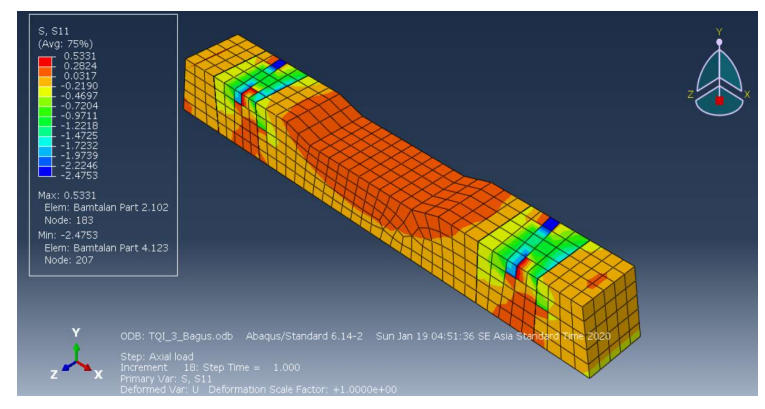

Gambar 10 Perilaku beton pada kondisi tanah bagus (Sand dense) dengan nilai spring $128.000 \mathrm{Kn} / \mathrm{m}^{3}$ dengan nilai penyimpangan TQI kategori 3 .

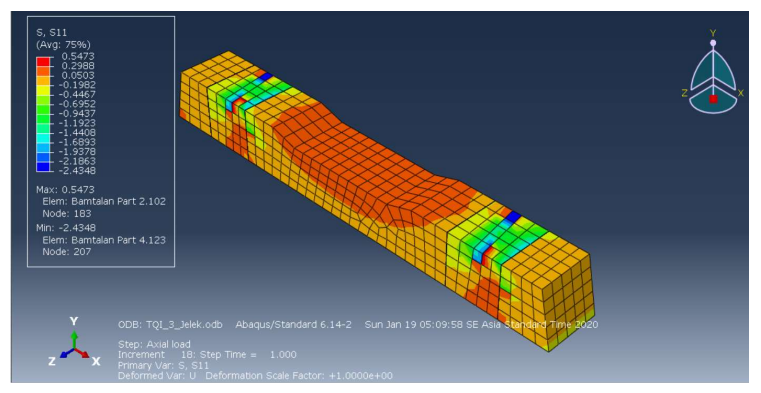

Gambar 11 Perilaku beton pada kondisi tanah sedang (Silty sand) dengan nilai spring $48.000 \mathrm{Kn} / \mathrm{m}^{3}$ dengan nilai penyimpangan TQI kategori 3

Hasil dari kondisi tanah sedang pada penyimpangan TQI kategori 3 adalah tensile stress $=5.544 \mathrm{MPa}$ dan compressive stress $=24.847 \mathrm{MPa}$.

Hasil dari kondisi tanah jelek pada penyimpangan TQI kategori 3 adalah tensile stress $=6.112 \mathrm{MPa}$ dan compressive stress $=25.628 \mathrm{MPa}$. Dari hasil analisa pada penyimpangan TQI kategori 3 pada ketiga kondisi tanah hasil maksimum tegangan tekan adalah $=26.626 \mathrm{MPa}<45.9 \mathrm{MPa}$ dan tegangan tarik $=6.112 \mathrm{MPa}>4.632 \mathrm{MPa}$, maka pada kondisi TQI 3 bantalan beton tidak mampu menahan gaya tarik yang disebabkan oleh momen yang bekerja akibat penyimpangan kategori 3 di buktikan dengan hasil diatas. Dari hasil analisa yang diakibatkan penyimpangan pada kategori 3 atau $25-40 \mathrm{~mm}$, bantalan sudah tidak bisa menahan beban tarik yang bekerja dengan kondisi beban maksimum $=9148 \mathrm{Kg}$ yaitu pada bantalan nomor 4 . Pengukuran nilai TQI dilapangan berjumlah 5 buah bantalan (3 meter) mengacu pada penelitian distribusi pembebanan yaitu sebesar 7\%, 23\%, 40\%, 23, $7 \%$ [15]. Dalam simulasi distribusi beban menggunakan stamformasi roda CC. Hasil simulasi finite elemen method sesuai dengan beban $\left(\mathrm{P}_{\text {aksial }}\right)$ yang bekerja pada masing - masing bantalan. Hasil tegangan tekan (compressive stress) dapat dilihat pada Gambar 13, serta hasil tegangan tarik (tensile stress) dapat dilihat pada Gambar 14. 


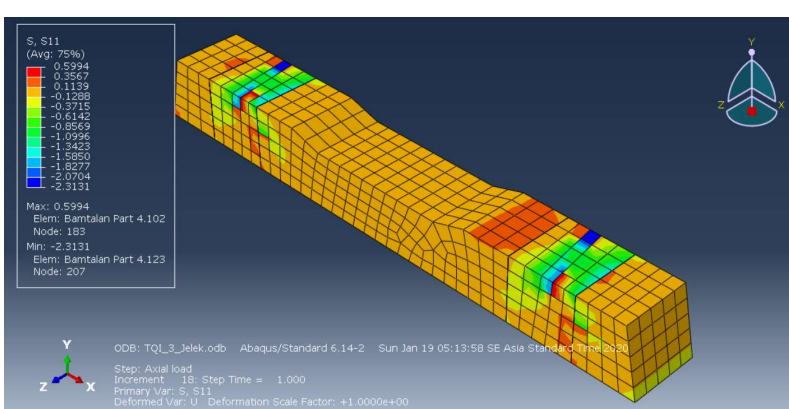

Gambar 12 Perilaku beton pada kondisi tanah jelek (Clay) dengan nilai spring $24.000 \mathrm{Kn} / \mathrm{m}^{3}$ dengan nilai penyimpangan TQI kategori 3.

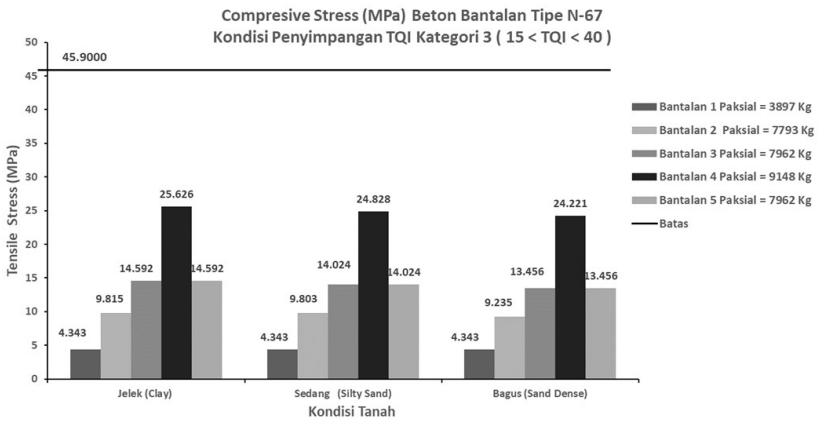

Gambar 13. Hasil analisa tegangan tekan (Compresive stress) pada setiap kondisi dengan nilai penyimpangan 25 $40 \mathrm{~mm}$.

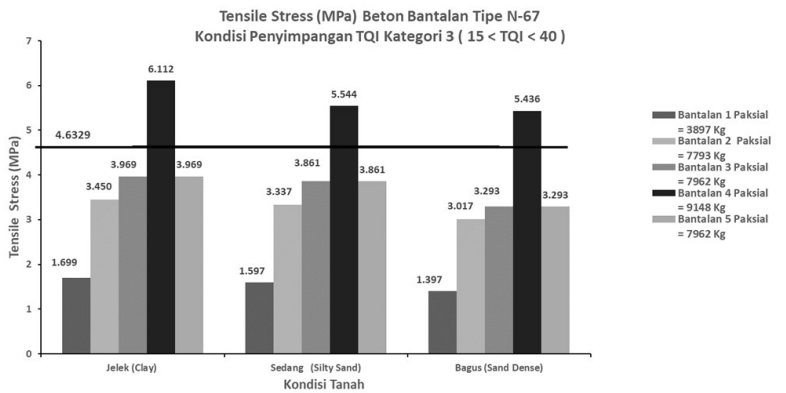

Gambar 14. Hasil analisa tegangan tarik (tensile stress) pada setiap kondisi dengan nilai penyimpangan $25-40 \mathrm{~mm}$.

\section{Kesimpulan dan Saran}

Perilaku bantalan beton pada kondisi penyimpangan TQI kategori $3(25<$ TQI $<40 \mathrm{~mm})$ beton tidak dapat menumpu beban tarik yang bekerja pada kondisi beban maksimum sebesar $9148 \mathrm{Kg}$, karena ada penambahan momen yang diakibakan penyimpangan geometri sebesar $173812 \mathrm{~kg} . \mathrm{mm}$. Hasil tegangan tarik (tensile stress) $=6.112 \mathrm{MPa}>4.633$ MPa lebih besar dari batas tarik yang disyaratkan, sedangkan tegangan tekan (compresive stress) $=25.626 \mathrm{MPa}<45.9$ $\mathrm{MPa}$, masih memenuhi batas tekan dari beton $54 \mathrm{MPa}$. Kesimpulan yang dapat ditarik dari penelitian ini adalah pada kondisi kategori $3(25<\mathrm{TQI}<40 \mathrm{~mm})$ terdapat simulasi FEA beton tidak dapat menahan gaya tarik yang bekerja, maka disarankan nilai penyimpangan geometri sebaiknya pada kondisi $>25 \mathrm{~mm}$ atau minimal pada kondisi kategori 2. Serta diperlukannya inovasi batalan beton yang lebih kuat menahan gaya tarik seperti beton ECC, beton daktail dsb.

\section{Daftar Pustaka}

[1] A. Umbu, T. Amah, F. Pasila, And I. Budiono, "Simulasi Sistem Penjadwalan Kereta: Studi Kasus Daop VIII Jawa Timur,” Pp. 101-106, 2013.

[2] R. Ravitharan, A. Labrooy, H. Widyastuti, And W. K. Chiu, "Rail Infrastructure In Port City - Surabaya, Indonesia," Procedia Eng., Vol. 188, Pp. 486-492, 2017.

[3] A. Lasisi And N. Attoh-Okine, "Principal Components Analysis And Track Quality Index: A Machine Learning Approach," Transp. Res. Part C Emerg. Technol., Vol. 91, No. March 2018, Pp. 230-248, 2018.

[4] D. Rayhana, Ayi \& Parikesit, "Perencanaan Pemeliharaan Jalan Reldaop Vi Yogyakarta," Pros. Simp. Ii - Uniid 2017, No. September, Pp. 978-979, 2017.

[5] R. Setiwan, "Track Quality Index As Track Quality," Simp. Xix Fstpt, Univ. Islam Indones. 11-13 Oktober 2016 Consid., No. July, 2017.

[6] D. Purwanto, "Pengujian Bantalan Beton Untuk Track Jalan Kereta Api Sepur 1435 Mm Menggunakan Standar Uji Arema," Pp. 11-18, 2008.

[7] R. Puspasari, Dwi \& Djamaludin, "Kajian Kapasitas Lentur Dudukan Bantalan Rel Kereta Type Bt25 S35 E36," 2016.

[8] W. Kurniawan, "Tinjauan Volume Pemeliharaan Tahunan Jalan Rel Berdasarkan (Tqi)," J. Rekayasa Sipil Astonjadro, Vol. 4, No. 1067 Mm, Pp. 1-17, 2015.

[9] F. H. Jaya, "Evaluasi Struktur Atas Komponen Jalan Rel Berdasarkan Passing Tonnage ( Studi Kasus: Jalan Rel Lintas Tanjung Karang - Bekri )," Tapak Vol. 8 No. 1, Vol. 8, No. 1, Pp. 33-45, 2018.

[10] F. Rezaie, M. Bayat A., And S. M. Farnam, "Sensitivity Analysis Of Pre-Stressed Concrete Sleepers For Longitudinal Crack Prorogation Effective Factors," Eng. Fail. Anal., Vol. 66, Pp. 385-397, 2016.

[11] M. M. Attard And S. Setunge, "Stress-Strain Relationship Of Confined And Unconfined Concrete," Aci Mater. J., Vol. 93, No. 5, Pp. 432-442, 1996.

[12] J. B. Mander, Seismic Desain Of Bridge Piers. 1983.

[13] S. Kaewunruen, C. Ngamkhanong, And C. H. Lim, "Damage And Failure Modes Of Railway Prestressed Concrete Sleepers With Holes/Web Openings Subject To Impact Loading Conditions," Eng. Struct., Vol. 
176, No. March, Pp. 840-848, 2018.

[14] M. A. Rofiq, H. Alrasyid, D. Iranata, And D. Irawan, "Prediksi Perilaku Lentur Kolom Beton Bertulang Mutu Tinggi Terhadap Kombinasi Beban Perpindahan Monotonik Dan Aksial Rendah,” J. Apl. Tek. Sipil, Vol. 17, No. 1, P. 43, 2019.

[15] B. Muthohar, Imam \& Santoso, "Analisis Distribusi Beban Kereta Api Pada Konstruksi Timbunan Jalur Kereta Api," 18th FSTPT Int. Symp. Unila, Bandar Lampung, August 28th, 2015, pp. 1418-1431, 2015.

[16] H. Panjaitan and Sembiring, "Evaluasi Komponen Jalan Rel Berdasarkan Passing Tonnage Dan Analisis Kebutuhan Pemeliharaan Tahunan Jalan Rel Dengan Analisa Jo Tahun 2011," J. Tek. Sipil ITP Vol. 4 No.2 Juli 2017, vol. 2011, 2011.

[17] J. E. Bowles, Foundation Analysis and Design Fifth Edition, vol. 20, no. 3. 1997. 